https://doi.org/10.17816/MAJ191S112-14

\title{
STATE OF CYTOKINES, ALPHA-AMYLASE AS A MARKERS OF AUTONOMOUS NERVOUS SYSTEM AND CORRECTION WATER DRINKING BEHAVIOR
}

\author{
G.M. Baisheva ${ }^{1}$, K.N. Melnik ${ }^{2}$ \\ ${ }^{1}$ Samara state medical university, Samara, Russia; \\ ${ }^{2}$ Togliatti city clinical hospital, Togliatti, Russia
}

\section{ЦИТОКИНЫ И АЛЬФА-АМИЛАЗА В КАЧЕСТВЕ МАРКЕРОВ АВТОНОМНОЙ НЕРВНОЙ СИСТЕМЫ ПРИ ИЗМЕНЕНИИ ПИТЬЕВОГО ПОВЕДЕНИЯ}

\author{
Г.М. Баишева ${ }^{1}$, К.Н. Мельник ${ }^{2}$
}

${ }^{1}$ ФГБОУ ВО «Самарский государственный медицинский университет» Минздрава России, Самара;
${ }^{2}$ ГБУЗ СО «Тольяттинская городская клиническая больница № 5», Тольятти

The aim. Detect the relationship between sympathetic activity, secretory alpha-amylase (sAA) indices and mediators of the immune system in healthy young volunteers (18-20 years) with correction drinking behavior (use pure water of $35 \mathrm{ml} /(\mathrm{kg}$ body weight)). Materials and methods. A randomized, placebo-controlled double-blind study, which was carried out in 3 stages $(09 / 20 / 2014 ; 08 / 11 / 2014 ; 12 / 13 / 2014)$ into 3 groups (test, placebo and control). The material used was saliva, in which IL-1 $\beta$, IL-4, IL-6 were detected by ELISA and the activity of alpha-amylase (sAA) was determined colorimetrically on an automatic analyzer; the level of sympathicotonia was determined by calculating the Kerdo-index. Results. A decrease in the activity of sAA test and placebo groups to the second stage, and the preservation of this trend in these groups by the end of the study, in contrast to the increase in its activity in the control group. The ratio of IL-1 $3 /$ IL- 6 at the third stage (MCC, $p=0.048$ ) in the test and placebo groups (146.66 and 111.61, respectively) exceeded (by 3 times and 2.4 times respectively) this indicator control group. In a subpopulation with a predictor of inflammatory diseases (PID) of the oral cavity (IL-1 $\beta \geq 212 \mathrm{pg} / \mathrm{ml}$ ) of the experimental group, the average IL-1 $\beta$ decreased to the third stage by $27 \%$ (from $247.7 \mathrm{pg} / \mathrm{ml}$ to $194.4 \mathrm{pg} / \mathrm{ml}$ ), in the placebo group, a similar decrease was $31.5 \%$ (from $243.24 \mathrm{pg} / \mathrm{ml}$ to $184.96 \mathrm{pg} / \mathrm{ml}$ ), while in the control the level of IL-1 $\beta$ remained at the same level (about $250 \mathrm{pg} / \mathrm{ml}$ ), $p>0.05$. By the end of the research, the Kerdo index showed a predominance in the test group of participants with parasympathicotonia (66.67\%), while in the placebo group this figure was $58.33 \%$, and in the control $50 \%$. Conclusion. The obtained data suggest an immunomodulatory effect of the use of $35 \mathrm{ml} /(\mathrm{kg}$ body weight) of pure water (clean by the physical method) against a decrease in sympathicotonia.

Keywords: cytokines; amylase; saliva; pure water; autonomic nervous system.

Цель работь - обнаружение взаимосвязи между симпатической активностью, показателями секреторной альфа-амилазы (sAA) и медиаторами иммунной системы при изменении питьевого поведения (употребление доочищенной электромагнитным прибором питьевой воды из расчета 35мл/кг веса) у здоровых молодых добровольцев (18-20 лет). Материалы и методы. Рандомизированное плацебо-контролируемое двойное слепое исследование, проходившее в 3 этапа (20.09.2014; 08.11.2014; 13.12.2014) в 3 группах (опыт, плацебо и контроль). Материалом служила ротовая жидкость, в которой детектировали ИЛ-1 $\beta$, ИЛ-4, ИЛ-6 методом ИФА и колориметрически определяли активность sAA на автоматическом анализаторе; уровень симпатикотонии выясняли путем расчета индекса Кердо. Результаты. Выявлено снижение активности sAA опытной и плацебо группах ко второму этапу, и сохранение данной тенденции в этих группах к концу исследования в отличие от повышения ее активности у контрольной группы. Соотношение ИЛ-1ß/ИЛ-6 на третьем этапе $($ ККУ, $p=0,048)$ в группах опыта и плацебо (146,66 и 111,61 соответственно) превосходило (в 3 раза и в 2,4 раза соотв.) данный показатель в группе контроля. В субпопуляции с предиктором воспалительных заболе-

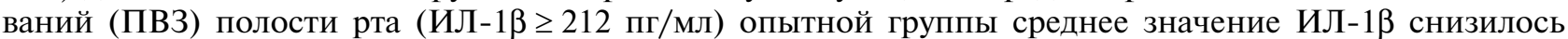
к третьему этапу на $27 \%$ (с 247,7 пг/мл до 194,4 пг/мл), в плацебо-группе аналогичное снижение составило 31,5\% (с 243,24 пг/мл до 184,96 пг/мл), в то время как в контроле уровень ИЛ-1 $\beta$ оставался на одном уровне (около 250 пг/мл), $p>0,05$. Индекс Кердо к концу работы показал преобладание в опытной группе участников с парасимпатикотонией $(66,67 \%)$, в то время как в плацебо-группе данный показатель составил $58,33 \%$, а в контроле $50 \%$. Заключение. полученные данные позволяют предположить иммуномодулирующее влияние употребления 35 мл/(кг массы тела) воды (обработанной физическим способом) на фоне снижения симпатикотонии.

Ключевые слова: цитокины; альфа-амилаза; ротовая жидкость; питьевая вода; симпатикотония. 
Introduction. Cytokines coordinate and regulate communication in the neuro-endocrine-immune network, affects the stress-related activity of the autonomic nervous system (ANS) and the hypothalamic-pituitary-adrenal axis (HPA) [1], also its affect the level of activity and sensitivity discharges of sympathetic and parasympathetic nerves, initiate immunomodulatory reactions (sympatheticimmune interaction) [2]. Alpha-amylase (sAA) is a link between the autonomic nervous and immune systems. The autonomic nervous system plays an important role in secreting sAA with the contribution of both alpha adrenergic and beta-adrenergic mechanisms, therefore sAA can be considered as an indirect indicator of its activation [3], to be a marker of stress-induced sympathetic nervous system activity [4]. The aim is to detect the relationship between sympathetic activity (determine the Cerdo index), sAA and citokynes (IL-1 $\beta$, IL-4, IL-6) in healthy young volunteers with correction water drinking behavior.

Materials and methods. The object of randomized, placebo-controlled, double-blind study were 85 young healthy people (18-20 years). All participants were selected according to the inclusion-exclusion criteria [5]. The study population was randomized in three groups: 1) an test group of 30 people who for 3 months (3 stages: 09/20/2014; $08 / 11 / 2014 ; 12 / 13 / 2014)$ used pure drinking water daily $(35 \mathrm{ml}$ per $1 \mathrm{~kg}$ of body weight cleaned with the help of the Aquadisk electromagnetic device (Aqua-Sistema, Moscow); 2) placebo group 30 students consumed drinking water for 6 months in the experimental group mode using the Aquadisk placebo device (without an electromagnetic device); 3 ) the control group -25 people who adhered to the usual water drinking behavior both in quantity and quality of the consumed fluid. Also participants were divided into subpopulations depending on the content of saliva IL- $1 \beta$ : IL- $1 \beta \leq 212 \mathrm{pg} / \mathrm{ml}$ (without predictor of inflammatory diseases of the oral cavity (without PID)) and IL-1 $\beta>212 \mathrm{pg} / \mathrm{ml}$ (with PID). The object for the study was saliva. The collection, transportation, processing and storage of biomaterial was carried out according to standardized protocols. The level of sAA activity was measured colorimetrically using a Cobas C111 automatic analyzer (Roche) and test systems from the same company. The number of cytokines was detected by ELISA on an Infinity F50 photometer (Tecan), using test systems from VectorBest (Novosibirsk). The Kerdo index (indicator of VNS activity evaluation) was calculated using the formula Index $=100 \times(1-\mathrm{DP} /$ Pulse $)$, where DP is the diastolic pressure in $\mathrm{mm} \mathrm{Hg}$; Pulse - heart rate per minute). A positive value of this index indicates the predominance of sympathetic influences in the ANS activity, a negative one - about the predominance of parasympathetic influences, "0" about functional equilibrium. Statistical processing included non-parametric Kruskal-Wallis analysis of variance (KWA), as well as pairwise comparisons of groups using the Mann-Whitney-Wilcoxon nonparametric criterion (MWWC). The numerical values of biochemical parameters are given as average or median (Me) and quartiles $(25 \%-75 \%)$. Differences between variation series were considered statistically significant at $p<0.05$.

Results and discussion. Activity of sAA decrease in test (from $\mathrm{Me}=272.2 \mathrm{U} / \mathrm{ml}(25 \%-75 \%=$ $=125.8-426.9)$ to $167.9(25 \%-75 \%=35.0-308.4)$, $p>0.05$ ) and placebo groups (from $371.2 \mathrm{U} / \mathrm{ml}$ $(25 \%-75 \%=116.1-714.6)$ to $259.9(25 \%-75 \%=$ $=0.1-401,2), p=0.05)$ at the second stage, and the preservation of this trend in these groups by the end of the study (test $-249.9 \mathrm{U} / \mathrm{ml}$ $(25 \%-75 \%=112.0-475.1)$, placebo $-292.5 \mathrm{U} / \mathrm{ml}$ $(25 \%-75 \%=121.1-529.9))$ in contrast to the increase in its activity in the control group (from $395.5 \mathrm{U} / \mathrm{ml}(25 \%-75 \%=137.1-889.5)$ in the first stage to $565.9 \mathrm{U} / \mathrm{ml}(25 \%-75 \%=122.4-852.5)$ in the third).

The cytokine profile for median indices was within the normal range without significant shifts both between and within groups, except for the IL-1 $\beta /$ IL-6 ratio at the third stage (KWA, $p=0.048)-$ the value in the experience groups and placebo (146.66 and 111.61, respectively) exceeded by 3 times (for experience, MWWC $p=0.026$ ) and 2.4 times (for placebo, MWWC $p=0.048$ ) this indicator in the control group.

The division of participants in the subpopulations revealed a tendency to a decrease in pro-inflammatory cytokines in the saliva. In the subpopulation with PID (IL-1 $1 \beta 212 \mathrm{pg} / \mathrm{ml}$ ): in the test group, the average value of IL-1 $\beta$ decreased to the third stage by $27 \%$ (from $247.7 \mathrm{pg} / \mathrm{ml}$ to $194.4 \mathrm{pg} / \mathrm{ml}$ ), in the placebo to the group, the reduction was $31.5 \%$ (from $243.24 \mathrm{pg} / \mathrm{ml}$ to $184.96 \mathrm{pg} / \mathrm{ml}$ ), while in the control the level of IL-1 $\beta$ remained at the same level $(250 \mathrm{pg} / \mathrm{ml}), p>0.05$ for all of the above changes. The average IL-1 $\beta / \mathrm{IL}-4$ ratio in the test group to the final stage of the study decreased by 11.6 times (from 202.42 in the first stage to 17.4 in the third stage), which implies the immunomodulation effect of corrected drinking behavior. In the same subpopulation of the placebo group, an increase in the IL-1 $\beta /$ IL- 4 ratio by $18.8 \%$ was observed (from 132.56 to 163.21), which according to the literature indicates a Th1-polarization of the immune response [6].

Statistically significant changes in the Cerdo index were recorded using analysis of variance (ANOVA) at stages 1-3 of the study in a subpopulation of IL $>212$ between the test groups (average values of the index $12.68 \pm 4.38)$ and placebo $(7.25 \pm 7.95)$. In relative figures, this was reflected in the prevalence in the test group of participants with parasympathicotonia (66.67\%), while in the placebo group this figure was $58.33 \%$, and in the control $50 \%$. 
Conclusion. A decrease in the activity of sAA as a marker of a decrease in the activity of the sympathetic nervous system of the test group and a placebo group in the second and third stages of the study, in contrast to an increase in its activity in the control group in the third stage, correlates with a decrease in the activity of the sympathetic nervous system according to the Cerdo test groups and placebo, which may indirectly indicate a more successful adaptation to stress in individuals who use water in accordance with physiological need. Cytokine levels and the ratio of IL-1 $\beta /$ IL- 6 and IL-1 $\beta /$ IL- 4 show a shift of markers of the immune response in favor of anti-inflammatory (given that IL-6 is able to exert reciprocal inhibition of IL-1 $\beta$ ) in the experience and placebo groups, which testifies to the immunomodulation effect of correcting drinking behavior with the use of water, clean in a physical way.

\section{References}

1. Irwin MR, et al. Reciprocal regulation of neural and innate immune systems. Nature Reviews. Immunology. 2011;11(9):625-632.

2. Kenney MJ, et al. Autonomic nervous system and immune system interactions. Compr Physiol. 2014;4(3):1177-1200.

3. Rohleder N, et al. Determinants of salivary $\alpha$-amylase in humans and metodological considerations. Psychoneuroendocrinology. 2009;34:469-485.

4. Cozma S, et al. Salivary cortisol and $\alpha$-amylase: subclinical indicators of stress for cardiometabolic risk. Braz J Med Biol Res. 2017;50(2):e5577.

5. Melnik KN, Baisheva GM, Gilmiyarova FN, Alpatova TA. Salivadiagnosis as a method for determining immunological adaptation to learning stress in different drinking behavior. Clinical laboratory diagnostics. 2018;63(6):353-357.

6. Panahov NA, Makhmudov TG. Assessment of parameters of local immune protection in patients with dental implants. Bulletin of the Kyrgyz-Russian Slavic University. 2017;17(10):82-86. 